\title{
Bovine brucellosis in slaughterhouses controlled by Federal and Municipal Inspection Services in the state of Maranhão, Brazil
}

\author{
Brucelose bovina em frigoríficos com Serviços \\ de Inspeção Federal e Municipal no estado do Maranhão
}

\author{
Anna Karoline Amaral Sousa' ${ }^{(D)}$, Bruno Raphael Ribeiro Guimarães ${ }^{2}$ (D), Priscila Alencar Beserra' (D), \\ Danilo Cutrim Bezerra' ${ }^{1}$, Ferdinan de Almeida Melo' ${ }^{1}$, Hamilton Pereira Santos' ${ }^{1}$, \\ Nancyleni Pinto Chaves Bezerra1* (D)
}

\begin{abstract}
The aims of the current study were to investigate the prevalence of bovine brucellosis, to correlate laboratory results of serum reactive samples to the serology of animals presenting serous pouches, and to identify possible risk factors for the development of the disease. In order to do so, 1,265 bovine blood samples were collected from male and female animals bred in different counties in Maranháo state, Brazil, and in other regions of the country. The animals were slaughtered in two slaughterhouses controlled by the Federal Inspection Service (FIS), and in two others controlled by the Municipal Inspection Service (MIS), of regions such as Açailândia and Imperatriz. Samples were tested for specific antibodies by using buffered acidified antigen (BAA) and 2-mercaptoethanol in combination with slow serum agglutination (2-ME + SSA). Additionally, an epidemiological questionnaire was applied to 100 owners, who provided animals to the slaughterhouses, to enable investigating the risk factors for bovine brucellosis. Fifteen serous pouches of animals presenting this lesion were also collected at slaughter time. Thirty-nine out of the analyzed samples were reacted to BAA, whereas 15 reacted to the 2-ME + SSA test; only one male was reagent and it resulted in $1.19 \%$ prevalence. One out of the 15 collected serous pouches reacted to the 2-ME + SSA test. The risk factors identified in this study were: the incidence of miscarriages, the sale of animals without previous examination, and the failure in testing the animals before introducing them in herds and before slaughter. It was possible to conclude that the animals slaughtered in the herein evaluated slaughterhouses were infected with Brucella abortus, as well as that this infection prevailed in females.
\end{abstract}

KEYWORDS: Brucella abortus; cattle; occupational disease; zoonoses; slaughterhouse.

\begin{abstract}
RESUMO: Os objetivos do estudo foram determinar a prevalência da brucelose bovina, relacionar resultados laboratoriais de amostras séricas reagentes com a sorologia de animais que apresentavam bursites e, ainda, identificar possíveis fatores de risco para a enfermidade. Para isso, no abate foram coletadas 1.265 amostras de sangue bovino, entre machos e fêmeas, procedentes de diferentes municípios maranhenses e de outras regióes do Brasil, abatidos em dois frigoríficos com Serviço de Inspeção Federal e dois com Serviço de Inspeção Municipal, nas regionais de Açailândia e Imperatriz. As amostras foram testadas para a presença de anticorpos específicos pelos testes do antígeno acidificado tamponado e 2-mercaptoetanol combinado à soroaglutinação lenta (2-ME + SAL). Para realizar o estudo dos fatores de risco, adicionalmente aplicou-se um questionário epidemiológico com 100 proprietários que forneceram animais aos frigoríficos. Foram também coletadas 15 amostras de material de bursite de animais que apresentaram a referida lesão no momento do abate. Do total de amostras analisadas, 39 foram reagentes ao antígeno acidificado tamponado e 15 foram confirmadas no 2-ME + SAL. Apenas um macho foi reagente, o que resultou em prevalência de $1,19 \%$. Das 15 amostras de material de bursites coletadas, uma foi reagente no teste 2-ME + SAL. Os fatores de risco identificados no estudo foram: ocorrência de abortamentos, venda de animais sem exames e não realização de exames que atestem os animais antes da inclusão nos rebanhos para abate. Concluiu-se que a infecção por Brucella abortus em animais abatidos nos frigoríficos avaliados está presente e ocorre com maior frequência em fêmeas.
\end{abstract}

PALAVRAS-CHAVE: Brucella abortus; bovinos; doença ocupacional; zoonoses; matadouro.

\footnotetext{
'Universidade Estadual do Maranhão, Programa de Pós-graduação Profissional Defesa Sanitária Animal (Curso de Mestrado) - São Luís (MA), Brazil ${ }^{2}$ Ministério da Agricultura, Pecuária e Abastecimento - São Luís (MA), Brazil

*Corresponding author: nancylenichaves@hotmail.com

Received on: 10/18/2017. Accepted on: 12/10/2018
} 


\section{INTRODUCTION}

Brucellosis stands out among diseases of economic importance and public health concern, since it is an infectious and contagious disease whose etiological agents are bacteria belonging to genus Brucella. This cosmopolitan and endemic zoonosis causes economic losses (such as loss of credibility in beef exports) and has impact on public health in several countries (BRASIL, 2006; SOLA et al., 2014).

Cattle infection by Brucella abortus causes economic issues in beef production, because, according to PAULIN; FERREIRA NETO (2003), it mainly affects the reproductive and osteoarticular systems of these animals, besides causing miscarriages in the final third of gestation, birth of weak animals, decreased milk production, orchitis, epididymitis and infertility. In agreement with MINERVINO et al. (2011), the disease is systemic in humans.

Brucellosis is transmitted to humans through the intake of contaminated meat, milk and its derivatives, as well as through the contact with blood, fetal remains, animal carcasses, fetuses and fluids from infected animals (PAULIN; FERREIRA NETO, 2003). The transmission between animals take place through the contact with dead fetuses and through artificial insemination (LAGE et al., 2008). According to SANTOS et al. (2007) and VIANA et al. (2010), brucellosis can be classified as an occupational disease, since livestock workers, butchers, slaughtermen and veterinarians are exposed to the risk of infection on a daily basis.

Slaughter technology methodologies adopted to assess the health of animals to be slaughtered consist in ante-mortem and post-mortem inspections. However, post-mortem inspections present aggravating factors such as the exposure of veterinarians and slaughterhouse employees to meat, blood, viscera, feces, urine, vaginal or uterine secretions, placental remnants, amniotic fluid and aborted fetuses, which may be infected (DIAS, 2012).

Veterinarians performing routine sanitary meat inspections do not count on specific diagnostic tools capable of associating changes observed in the post-mortem inspection with brucella infection (FREITAS; OLIVEIRA, 2005). This challenge converges to the pursuit of alternatives capable of assuring the safe and quick diagnosis of several lesions identified in slaughtered animals during inspections conducted in slaughterhouses. According to VIANA et al. (2010), the safe diagnosis of bovine brucellosis in slaughterhouses cannot be only based on the investigation of signs or lesions, since they are rarely, and not easily, found in ante- and post-mortem examinations. Therefore, based on SOLA et al. (2014), the real challenge lies on the pursuit of alternatives capable of assuring the safe and quick diagnosis of several lesions identified in slaughtered animals during inspections conducted in slaughterhouses.

It is essential conducting studies about the impact of brucellosis on animal breeding systems such as decreased production and reproduction indices, as well as about the strong association of this zoonosis with certain professional classes. Given the importance of conducting studies in slaughterhouses to collect primary epidemiological data, we herein conducted an epidemiological study about bovine brucellosis in slaughterhouses controlled by Federal (FIS) and Municipal Inspection Services (MIS) in Maranhão state, Brazil.

The aims of the current study were to investigate the prevalence of bovine brucellosis (Brucella abortus) in blood serum samples collected from slaughtered animals, to correlate laboratory results of serum reactive samples to the serology of animals presenting serous pouches in post-mortem examinations, as well as to identify possible risk factors for brucellosis in slaughtered cattle.

\section{MATERIALS AND METHODS}

This study was carried out in four slaughterhouses located in Imperatriz and Açailândia regional units, in Maranhão state, Brazil. Two of them were controlled by MIS and the other two by FIS. These slaughterhouses slaughter approximately 150 to 400 cattle/day, respectively; and the animals come from different counties and from other Brazilian states, such as Pará and Tocantins. Samples were collected from October 2015 to September 2016 and analyzed in October 2016, thus totaling 12 months of study. Data such as sex, chronological age and origin of the animals were collected in the official records - Animal Transport Permit (ATP) — of the herein investigated slaughterhouses.

The herein studied population comprised 24-month-old (or older) male and female cattle destined for slaughter. The formula suggested by TRIOLA (1999) and CALLEGARI-JACQUES (2003) was used to calculate the sample size by taking into consideration the daily slaughter capacity of the four herein investigated slaughterhouses, at 5\% sampling error and 95\% confidence level $(\mathrm{Z})$. The number of animals was proportionally distributed based on the number of animals slaughtered by each establishment during the studied period.

A 10-mL aliquot of blood was collected in sterile test tubes without anticoagulant agent, at cattle bleeding time. After that, the test tubes were placed in $45^{\circ}$-angle position and kept at room temperature, away from the light, to enable blood clotting. Subsequently, they were packed in isothermal boxes filled with ice and sent to the Laboratory of Infectious Disease Diagnosis of the Veterinary Medicine course of Universidade Estadual do Maranhão (UEMA), where they were centrifuged at $1,500 \times \mathrm{G}$ for 10 minutes, in order to separate the serum. When the centrifugation procedure was over, serum aliquots were placed in $2 \mathrm{~mL}$ polypropylene plastic tubes (Eppendorf) and frozen at $-20^{\circ} \mathrm{C}$ for further laboratory tests.

A routine inspection was conducted by the inspectionservice staffs in the slaughter room of the herein investigated 
slaughterhouses. Adorso-ventral incision was made from the third thoracic vertebra between the cervical ligaments, and animals presenting morphological changes in the mucous membrane of the withers had the exudate and the fibrous part of the serous pouches collected. Serous pouches were removed - either intact or as they appeared after hemi-carcass separation — from their topographic locations and anatomical insertions through the sectioning of neighboring tissues. Next, they were placed in plastic bags, transported to the laboratory under refrigeration conditions, prepared for the aseptic collection of the exudate inside the pouches and kept in sterile plastic tubes at $-20^{\circ} \mathrm{C}$.

The current study was approved by the Ethics Committee on Animal Experimentation of UEMA Veterinary Medicine course - Protocol no. 15/2015.

Biological samples were subjected to indirect diagnostic methods based on antibody detection. Serum agglutination was subjected to buffered acidified antigen (BAA) or card tests, according to ALTON et al. (1988), as recommended by the Ministry of Agriculture, Livestock and Supply (Ministério da Agricultura, Pecuária e Abastecimento - MAPA) through the National Program for the Control and Eradication of Animal Brucellosis and Tuberculosis (Programa Nacional de Controle e Erradicação da Brucelose e da Tuberculose Animal — PNCEBT). Result interpretation was based on the presence (reactive animals) or absence (non-reactive animals) of serum agglutination. The 2-mercaptoethanol (2-ME) test was used in association with slow serum agglutination (SSA) to confirm the diagnosis, as recommended by MAPA/PNCEBT. More specifically, result interpretation was based on the serum agglutination level in different dilutions (1:25, 1:50, 1:100, 1:200), which was classified as complete $(+)$, incomplete (I) or negative (-). Test results were interpreted in compliance with PNCEBT standards (BRASIL, 2006).

An epidemiological questionnaire was applied to 100 cattle owners in order to collect information about farms, animals and about the management system to enable investigating possible risk factors associated with brucellosis. Variables analyzed in the epidemiological questionnaire were:

- breeding type;

- milking type;

- vaccination against brucellosis;

- conducting tests to diagnose brucellosis;

- buying and selling tested animals;
- incidence of miscarriages in the farm;

- reason for selling the animals;

- counting on veterinary medical assistance in the farm.

The association between seropositivity and the analyzed variables was subjected to univariate analysis through the Fisher's exact test, or through $\chi^{2}$ tests when the Fisher's test was not applicable, at 5\% significance level (0.05) and 95\% confidence interval. InStat 3.0 version 2008 was the statistical software used in the current study.

\section{RESULTS}

In total, 1,265 bovine serum samples were analyzed: 1,173 deriving from Maranhão state and 92 from Pará state. Thirty-nine out of the total analyzed samples were BAA-reactive, whereas 15 reacted to the 2-ME + SSA test (14 of them came from Maranhão and 1 from Pará).

Twelve out of the 415 FIS-controlled slaughterhouse samples collected in Imperatriz county were BAA-reactive, whereas eight reacted to the 2-ME + SSA test. Only one out of the 300 FIS-controlled slaughterhouse samples collected in Açailândia county was BAA-reactive. Twenty-four out of the 300 MIS-controlled slaughterhouse samples collected in Imperatriz county reacted to the BAA test, whereas seven reacted to the 2-ME + SSA test. Two out of the 250 MIScontrolled slaughterhouse samples collected in Açailândia county reacted to the BAA test. Table 1 summarizes the number of samples collected per slaughterhouse and per county, and their respective serology results.

The following titration was recorded for the 15 samples that reacted to the 2-ME + SSA test: five samples recorded titration 1/25; nine presented titration 1/50; and one, titration 1/100.

The comparison between tests showed differences between BAA (39 reactive samples) and 2-ME + SSA (15 reactive samples) results.

With respect to variable sex, 689 and 576 samples were collected from male and female animals, respectively. Only one out of the 689 tested male samples reacted to both BAA and 2-ME + SAA tests. Thirty-eight out of the 576 female samples

Table 1. Number of serum samples analyzed to identify anti-Brucella abortus antibodies, according to county and inspection service.

\begin{tabular}{lcccccc}
\multirow{2}{*}{ Slaughterhouse } & County & Sample & \multicolumn{4}{c}{ Laboratory tests } \\
\cline { 3 - 7 } & \multirow{2}{*}{ FIS } & & $\mathbf{n}$ & BAA (\%) & $\mathbf{n}$ & 2-ME + SSA (\%) \\
\cline { 2 - 7 } & Imperatriz & 415 & 12 & 0.94 & 8 & 0.63 \\
MIS & Açailândia & 300 & 1 & 0.07 & 0 & 0 \\
& Imperatriz & 300 & 24 & 1.89 & 7 & 0.55 \\
\hline
\end{tabular}

$\mathrm{N}$ : number of samples; BAA: buffered acidified antigen; 2-ME: 2-mercaptoethanol; SSA: slow serum agglutination; FIS: Federal Inspection Service; MIS: Municipal Inspection Service. 
were BAA-reactive, whereas 14 reacted to the $2-\mathrm{ME}+\mathrm{SSA}$ test (Table 2).

Table 3 summarizes the serological results of samples analyzed in the current study, based on inspection service and county of origin.

All samples were collected from animals that did not show indications/clinical signs of brucellosis in ante-mortem examinations or positive brucellosis results in previous serological tests.

A random collection conducted during carcass inspection in the slaughter room allowed identifying 15 animals presenting lesions that suggested brucellosis (serous pouches); the aforementioned lesions had granulomatous aspect, irregular shape, varying size, besides presenting, or not, liquid. The aforementioned samples were different from the serum samples randomly collected at cattle-bleeding time. After the material collection (serous pouches and blood serum), sample preparation and laboratory blood serum analysis were over, it was possible seeing that only one (6.67\%) out of the 15 serum samples collected from animals presenting serous pouches reacted to the 2-ME + SSA test.

Based on univariate analysis results (Table 4), variables "incidence of miscarriage in the farm", "selling untested animals", and "not conducting periodic brucellosis tests" were statistically associated with the incidence of the disease $(\mathrm{p}<0.05)$.

\section{DISCUSSION}

Bovine brucellosis recorded $1.19 \%$ prevalence in the current study $(\mathrm{n}=15 / 1,265)$. This value was lower than the one recorded by SANTOS et al. (2007), who carried out a seroepidemiological study in a MIS-controlled slaughterhouse in São Luís county,
Maranhão state, and found mean brucellosis prevalence of $3.28 \%$. PRAZERES et al. (2014), BORBA et al. (2013), CARVALHO et al. (2016), DUTRA (2015) and LIMA (2015) also conducted studies about bovine brucellosis in Maranhão and recorded 3.94, $2.52,4.95,2.21$ and $8.4 \%$ prevalence of the disease, respectively; all the aforementioned results were higher than the one recorded in the present study. However, MARTINHO et al. (2011) conducted a study about bovine brucellosis in the municipal slaughterhouse of Imperatriz county and recorded $0.03 \%$ prevalence of lesions suggesting brucellosis in the analyzed carcasses - this value was lower than the one found in the present study.

The comparison between our brucellosis prevalence results and the ones presented before allowed inferring that brucellosis remains a common issue and a major concern despite the set of official sanitary actions taken over the last decades in virtually all Brazilian regions.

According to PNCEBT, there may be false-positive reaction cases between the BAA and 2-ME + SSA tests due to the application of the B19 vaccine in calves after the recommended age (3-8 months), as well as to non-specific antibodies often found in infections caused by other bacteria such as Salmonella sp., Escherichia coli O:157, Pseudomonas sp. or Yersinia enterocolitica (BRASIL, 2006). There were non-specific reactions in samples subjected to 2-ME and SSA tests, possibly due to vaccinations carried out after the period recommended by PNCEBT. Although vaccination against brucellosis is a mandatory procedure in the studied area, it is likely that herd immunization is not carried out as officially required.

According to the simple comparative analysis applied to female sample results based on Inspection Service, 13 out of the 38 females reacting to the BAA test came from FIS-controlled slaughterhouses, whereas 25 came from the MIS-controlled ones. Based on the confirmatory test results, eight positive samples

Table 2. Serological results of serum samples collected from male and female animals to identify anti-Brucella abortus antibodies, according to the county of origin.

\begin{tabular}{|c|c|c|c|c|c|c|c|}
\hline \multirow{3}{*}{$\begin{array}{l}\text { Animals } \\
\text { Males }\end{array}$} & \multicolumn{3}{|c|}{ Imperatriz } & \multicolumn{4}{|c|}{ Açailândia } \\
\hline & $\mathrm{n}$ & BAA & $2 \mathrm{ME}+\mathrm{SSA}$ & \multirow{2}{*}{ Males } & $\mathrm{n}$ & BAA & $2 \mathrm{ME}+\mathrm{SSA}$ \\
\hline & 339 & 1 & 1 & & 350 & 0 & 0 \\
\hline \multirow{2}{*}{ Females } & $\mathrm{n}$ & BAA & $2 \mathrm{ME}+\mathrm{SSA}$ & \multirow{2}{*}{ Females } & $\mathrm{n}$ & BAA & $2 \mathrm{ME}$ \\
\hline & 376 & 35 & 14 & & 200 & 3 & 0 \\
\hline Total & 715 & 36 & 15 & Total & 550 & 3 & 0 \\
\hline
\end{tabular}

$\mathrm{N}$ : number of samples; BAA: buffered acidified antigen; 2-ME: 2-mercaptoethanol; SSA: slow serum agglutination.

Table 3. Serological results of bovine serum samples collected to identify anti-Brucella abortus antibodies, according to the Inspection Service in the slaughterhouses and to the county of origin.

\begin{tabular}{|c|c|c|c|c|c|c|c|c|c|c|}
\hline \multirow{2}{*}{ County } & \multicolumn{5}{|c|}{ Federal Inspection } & \multicolumn{5}{|c|}{ Municipal Inspection } \\
\hline & $\mathbf{n}$ & BAA & $\%$ & $2 M E+S S A$ & $\%$ & $\mathbf{n}$ & BAA & $\%$ & $2 M E+S S A$ & $\%$ \\
\hline Imperatriz & 415 & 12 & 0.94 & 8 & 0.63 & 300 & 24 & 1.89 & 7 & 0.55 \\
\hline Açailândia & 300 & 1 & 0.07 & - & - & 250 & 2 & 0.15 & - & - \\
\hline
\end{tabular}

$\mathrm{N}$ : number of samples; BAA: buffered acidified antigen; 2-ME: 2-mercaptoethanol; SSA: slow serum agglutination. 
were identified in FIS-controlled slaughterhouses and six were identified in the MIS-controlled ones; all animals were bred in Maranhão state. Only one male tested positive for brucellosis in the herein conducted tests; the aforementioned animal was bred in Itupiranga county (Pará state) and it was slaughtered in a MIScontrolled slaughterhouse in Imperatriz county, Maranhão state.

FREITAS; OLIVEIRA (2005) and SANTOS et al. (2007) reported higher brucellosis prevalence in female than in male animals, fact that corroborates the present study. B. abortus reaches its highest concentration in the contents of the pregnant uterus, in the fetus and in fetal membranes, which should be seen as the major sources of infection (BLOOD; RADOSTITS, 1991). In addition, B. abortus is likely associated with the higher brucellosis incidence in female than in male animals. However, it is worth emphasizing that non-pregnant female, male and young female bovines are also susceptible to the disease, although to a lesser extent.

All the herein sampled animals did not present any indication, or clinical sign, of brucellosis in the ante-mortem examination, or tested positive for brucellosis in previous serological tests. These results, along with the ones recorded by VIANA et al. (2010), who identified $16.8 \%$ bovines with no signs of the disease, reinforce the importance of conducting studies in slaughterhouses to collect important epidemiological data.

Only one serous pouch sample $(6.67 \%)$ reacted to the serological tests. This number is lower than the one found by FREITAS; OLIVEIRA (2005) and ALMEIDA et al. (2000), who recorded 100 and $13.3 \%$ reaction in animals presenting serous pouches, respectively.
According to FREITAS; OLIVEIRA (2005), there is association between serous pouch lesions and brucellosis seropositivity. ALMEIDA et al. (2000) reported that animals who tested positive for brucellosis presented fibrin in the serous pouches, whereas the seronegative ones presented purulent or nodular lesions. ESTEVES et al. (2013) highlighted the importance of serous pouches as brucellosis-suggestive lesions, as well as that these pouches may be associated with other microorganisms, which can be causative agents of the lesions. On the other hand, SANTOS et al. (2016) attribute the incidence of lesions to coincidence and do not associate them with the disease.

According to SANTOS et al. (2016), studies focused on diagnosing brucellosis, mainly in animals destined for slaughter, remain scarce in the literature. Animals who just present the lesions should not be considered positive for brucellosis, just as animals who do not present any lesion type should not be considered negative. ESTEVES et al. (2013) reported that the presence of lesions is not sufficient to meet the sanitary requirements, since a large number of animals can be positive without presenting characteristic lesions of the disease.

Variable "miscarriage" was considered a risk factor in the present study ( $p$ < 0.0021). According to MOTA (2011), miscarriages and birth of weak calves are often clinical signs of brucellosis.

Variable "selling untested animals" was considered a risk factor in the present study $(\mathrm{p} \leq 0.0136)$. The trade of untested animals between neighboring farms favors the circulation of brucellosis in the studied region. According to MOTA (2011), the real issue lies on the acquisition of animals who were not

Table 4. Risk factors associated with brucellosis in cattle slaughtered in slaughterhouses controlled through Federal and Municipal Inspection Services in Açailândia and Imperatriz regional units, Maranhão state, Brazil.

\begin{tabular}{|c|c|c|c|c|c|c|c|c|c|c|}
\hline \multirow{3}{*}{ Variables } & & \multicolumn{9}{|c|}{ Brucellosis } \\
\hline & & \multicolumn{2}{|c|}{ Reactive } & \multicolumn{2}{|c|}{ Non-reactive } & \multicolumn{2}{|c|}{ Total } & \multirow{2}{*}{ OR } & \multirow{2}{*}{$95 \% \mathrm{Cl}$} & \multirow{2}{*}{ p-value } \\
\hline & & $\mathbf{n}$ & $\%$ & $n$ & $\%$ & $n$ & $\%$ & & & \\
\hline \multirow{2}{*}{ Breeding type } & Beef & 8 & 7 & 86 & 72 & 94 & 78 & \multirow{2}{*}{2.326} & \multirow{2}{*}{$0.2773-19.502$} & \multirow{2}{*}{0.6819} \\
\hline & Dairy & 1 & 1 & 25 & 21 & 26 & 22 & & & \\
\hline \multirow{2}{*}{ Milking type } & Manual & 0 & 0 & 20 & 17 & 20 & 17 & \multirow{2}{*}{0.234} & \multirow{2}{*}{$0.0131-4.204$} & \multirow{2}{*}{0.2349} \\
\hline & No milking & 9 & 8 & 91 & 76 & 100 & 83 & & & \\
\hline \multirow{2}{*}{ Brucellosis tests } & Yes & 2 & 2 & 91 & 76 & 93 & 78 & \multirow{2}{*}{0.0627} & \multirow{2}{*}{$0.0121-0.3253$} & \multirow{2}{*}{$0.00004^{*}$} \\
\hline & No & 7 & 6 & 20 & 17 & 27 & 23 & & & \\
\hline \multirow{2}{*}{$\begin{array}{l}\text { Buys tested } \\
\text { animals }\end{array}$} & Yes & 3 & 3 & 48 & 40 & 51 & 43 & \multirow{2}{*}{0.6563} & \multirow{2}{*}{$0.1561-2.759$} & \multirow{2}{*}{0.7314} \\
\hline & No & 6 & 5 & 63 & 53 & 69 & 58 & & & \\
\hline \multirow{2}{*}{$\begin{array}{l}\text { Sells tested } \\
\text { animals }\end{array}$} & Yes & 0 & 0 & 45 & 38 & 45 & 38 & \multirow{2}{*}{0.0769} & \multirow{2}{*}{$0.0043-1.356$} & \multirow{2}{*}{$0.0136^{*}$} \\
\hline & No & 9 & 8 & 66 & 55 & 75 & 63 & & & \\
\hline \multirow{2}{*}{$\begin{array}{l}\text { Miscarriages } \\
\text { in the last } \\
12 \text { months }\end{array}$} & Yes & 5 & 4 & 11 & 9 & 16 & 13 & \multirow[b]{2}{*}{11.364} & \multirow[b]{2}{*}{$2.652-48.693$} & \multirow[b]{2}{*}{0.0021 * } \\
\hline & No & 4 & 3 & 100 & 83 & 104 & 87 & & & \\
\hline \multirow{2}{*}{$\begin{array}{l}\text { Veterinary } \\
\text { assistance }\end{array}$} & Yes & 2 & 2 & 15 & 13 & 17 & 14 & \multirow{2}{*}{1.829} & \multirow{2}{*}{$0.3465-9.650$} & 06135 \\
\hline & No & 7 & 6 & 96 & 80 & 103 & 86 & & & 0.0135 \\
\hline
\end{tabular}

OR: odds ratio; $95 \% \mathrm{Cl}$ : confidence interval of $95 \%$; ${ }^{*}$ statistical significance $(\mathrm{p} \leq 0.05)$. 
subjected to sanitary control examinations, i.e., untested animals whose health condition of the herd of origin is unknown.

"Failure to perform routine tests in the herds" was another variable considered a risk factor in the current study ( $\mathrm{p} \leq 0.0004)$. The lack of these tests in the herds makes it difficult for breeders to have information about the health of the herd and does not enable the implementation of adequate sanitary measures.

Based on the analysis applied to the herein collected data, as also reported by DUTRA (2015) and ROCHA ALENCAR (2016), one of the main issues for the incidence of brucellosis in bovine herds bred in Maranhão state lies on the lack of information at the time untested animals are acquired, on the control of positive animals, on sanitary and reproduction management, and on the type of production system implemented in the rural properties. ROCHA ALENCAR (2016) and BORBA et al. (2013) also emphasized the lack of veterinary assistance in the farms as a significant obstacle to the control of sanitary issues in the herds.

The epidemiological monitoring of the animals should also be considered a factor for brucellosis control, since sanitary documents showed that animals transported from other states, just as the ones bred in Maranhão, are declared as coming from farms presenting vaccination records. However, there is no information available about the vaccination status of these animals.

According to VIANA et al. (2010), the lack of information on animal health is the main risk factor for slaughterhouse workers. NOCITI et al. (2008) reported that the contact with brucellosis-infected animals in slaughterhouses during routine inspections or examinations was responsible for $67 \%$ contamination in slaughterhouses. SCHNEIDER et al. (2013) found $4.5 \%$ brucellosis prevalence in slaughterhouse workers, besides stating that the slaughter of infected animals is a considerable risk factor for brucellosis transmission to humans.

Although the vaccination of female animals is mandatory, it was possible seeing that the lack of tests capable of proving the absence of brucellosis in animals prior to slaughter can be a high-risk factor for slaughterhouse workers, veterinarians, slaughtermen and consumers, since the presence of suggestive lesions itself does not rule out the possibility of brucellosis in bovine carcasses.

\section{CONCLUSIONS}

Based on our results, it was possible to conclude that cattle slaughtered in slaughterhouses controlled by FIS and MIS in Imperatriz and Açailândia counties (Maranhão state) presented Brucella abortus infection, as well as that this infection prevailed in female animals. The main risk factors for the disease encompassed the incidence of miscarriages in the farm, the sale of untested animals, and the failure to test the animals before their introduction in the herds and before slaughter.

The active epidemiological monitoring of brucellosis should be adopted as routine activity in slaughterhouses, since it would help improve public and occupational health in these establishments. Information about animals suspected of being infected with brucellosis, and not only about the ones reporting positive results after slaughter, should be immediately reported by all slaughterhouses to official veterinary services.

It is essential performing the accurate diagnosis, eliminating positive animals and vaccinating the herds at the recommended age to enable disease control.

\section{ACKNOWLEDGMENTS}

The author is grateful to the Research Support Foundation for Scientific and Technological Development of Maranhão State (Fundação de Amparo à Pesquisa e ao Desenvolvimento Científico e Tecnológico do Maranháo - FAPEMA).

| | | | | | | | | | | | | | | | | | | | | | | | | | | | | | | | | | | | | | | | | | | | | | | | | | | | | | | | | | | | | | | | | | | | | | | | | | | | | | | | | | | | | | | | | | | | | | | | | | | | | | | | | | | | | | | | | | | | | | | | | | | | | | | | | | | | | | | | | | | | | | | | | | | | | | | | | | | | | | | | | | | | | | | | | | | | | | | | | | | | | | | | | | | | | | | | | | | | | | | | | | | | | | | | | | | | | | REFERENCES

ALMEIDA, L.P.; REIS, D.O.; GERMANO, P.M.L. Brucelose em bovinos com bursite cervical diagnosticada em abatedouro sob inspeção federal. Ciência Rural, v.30, n.2, p.287-291, 2000. Available from: http://www.scielo.br/scielo.php?script=sci_arttext\&pid=SO103$84782000000200015 \&$ Ing=pt\&tlng=pt. Accessed on: May 18 2017.http://dx.doi.org/10.1590/SO103-84782000000200015

ALTON, G.G.; JONES, L.M.; ANGUS, R.D.; VERGER, J.M. Techniques for the brucellosis laboratory. Paris: Institut National de La Recherche Agronomique, 1988.

BLOOD, D.C.; RADOSTITS, O.M. Clínica Veterinária. 7. ed. Rio de Janeiro: Guanabara Koogan, 1991.
BORBA, M.R.; STEVENSON, M.A.; GONÇALVES, V.S.; NETO, J.S.; FERREIRA, F.; AMAKU, M.; TELLES, E.O.; SANTANA, S.S.; FERREIRA, J.C.; LÔBO, J.R.; FIGUEIREDO, V.C.; DIAS, R. A. Prevalence and risk-mapping of bovine brucellosis in Maranhão State, Brazil. Preventive Veterinary Medicine, v.1 10, n.2, p.169-176, 2013. http://dx.doi.org/10.1016/j.prevetmed.2012.11.013

BRASIL. Ministério da Agricultura, Pecuária e Abastecimento. Manual Técnico do Programa Nacional de Controle e Erradicação da Brucelose e da Tuberculose Bovina (PNCEBT). Brasília: MAPA/ SDA/DAS, 2006. Available from: https://edisciplinas.usp.br/ pluginfile.php/3315534/mod_resource/content/1/MANUAL_ PNCEBT.pdf. Accessed on: May 102017. 
CALLEGARI-JACQUES, S.M. Bioestatística: princípios e aplicações. Porto Alegre: Artmed, 2003.

CARVALHO, R.F.B.; SANTOS, H.P.; MATHIAS, L.A.; PEREIRA, H.M.; PAIXÃO, A.P.; COSTA FILHO, V.M.; ALVES, L.M.C. Frequência de brucelose bovina em rebanhos leiteiros e em seres humanos na região central do estado do Maranhão, Brasil. Arquivos do Instituto Biológico, v.83, n.1-6, e1042014, 2016. Available from: http://www.scielo.br/pdf/aib/v83/1808-1657-aib83-e 1042014.pdf. Accessed on: May 10 2017. https://doi. org/10.1590/1808-1657001042014

DIAS, I.C.L. Prevenção de zoonoses ocupacionais em abatedouros de bovinos. Revista Eletrônica de Extensão da URI, v.8, n. 15, p.8998, 2012. Available from: http://www.reitoria.uri.br/ vivencias/ Numero_015/artigos/pdf/Artigo_07.pdf. Accessed on: May 102017.

DUTRA, M.C.C. Aspectos epidemiológicos da brucelose bovina no estado do Maranhão no período de 2008 a 2014. 2015. 71 f. Dissertação (Mestrado em Ciência Animal) - Universidade Estadual do Maranhão, São Luís, 2015. Available from: http:// www.cienciaanimal.uema.br/images/diss/diss-2015/maria\%20 cristina.pdf. Accessed on: May 172017.

ESTEVES, C.; ARAÚJO, M.M.B.; FARIA, P.B.; MASCARENHAS, D.R.; FARIA, J.H. Bursite cervical em bovinos e sua correlação com a brucelose. In: CONGRESSO DE PÓS-GRADUAÇÃO DA UFLA, 23. 2013. Lavras. Anais...Lavras: UFLA, 2013. p.1-6.

FREITAS, J.A.; OLIVEIRA, J.P. Pesquisa de infecção brucélica em bovídeos abatidos portadores de bursite. Arquivos do Instituto Biológico, São Paulo, v.72, n.4, p.427-433, out./dez. 2005. Available from: http://www.biologico.sp.gov.br/docs/arq/v72_4/ freitas.PDF. Accessed on: May 182017.

LAGE, A.P.; POESTER, F.P.; PAIXÃO, T.A.; SILVA, T.M.A.; XAVIER, M.N.; MINHARRO, S.; MIRANDA, K.L.; ALVES, C.M.; MOL, J.P.S.; SANTOS. R.L. Brucelose bovina: uma atualização. Revista Brasileira de Reprodução Animal, Belo Horizonte, v.32, n.3, p.202-212, jul./set. 2008. Available from: http://www.cbra.org.br/pages/ publicacoes/rbra/download/RB206\%20Lage\%20vr2\%20 pag202-212.pdf. Accessed on: May 182017.

LIMA, C.A.A. Diagnóstico soroepidemiologico da Brucella abortus na microrregião de Imperatriz - MA. 2015. Monografia (Graduação em Medicina Veterinária) - Universidade Estadual do Maranhão, São Luís, 2015.

MARTINHO, F.S.; SOUSA JUNIOR, F.G.; SILVA JUNIOR, D.S.; SANTOS, M.F.; GOMES, W.M.; CASTILLO, L.A.C. Diagnóstico da Brucelose em bovinos no abatedouro municipal de Imperatriz MA. Revista Agroecossistemas, v.3, n.1, p.41-44, 201 1. http:// dx.doi.org/10.18542/ragros.v3i1.1241

MINERVINO, A.H.H; CALHAU, A.S.; ALVES FILHO, A.; BARBOSA, R.S.; NEVES, K.A.L.; BARROS, I.O.; BARRETO, R.A.; ORTOLANI, E.L. Estudo retrospectivo da ocorrência de bovinos soro reagentes à brucelose no Estado do Pará. Acta Veterinaria Brasilica, v.5, n. 1, p.47-53, 2011 . Available from: https://periodicos.ufersa. edu.br/index.php/acta/article/view/1807/4779. Accessed on: May 102017 . https://doi.org/10.21708/avb.2011.5.1.1807
MOTA, A.L.A.A. Fatores de risco para brucelose bovina no Brasil. 2011. 73f. Dissertação (Mestrado em Saúde Animal) Universidade de Brasília, Faculdade de Agronomia e Medicina Veterinária, Brasília, 2011.

NOCITI, R.P.; NOCITI, D.L.P.; SILVA, G.C.P.; AVILA, M.O. Fatores de risco associados à brucelose em médicos veterinários com predisposição ocupacional no estado de Mato Grosso, Brasil. 2008. In: CONGRESSO BRASILEIRO DE MEDICINA VETERINÁRIA, 35., 2008, Gramado. Anais...Rio Grande do Sul: Sovergs, p. 19-22, 2008.

PAULIN, L.M.; FERREIRTA NETO, J.S. O combate á brucelose bovina: situação brasileira. Jabuticabal: FUNEP, 2003. 154p.

PRAZERES, M.P.C.S.; CHAVES, N.P.; SANTOS, A.M.; CARVALHONETA, A.V.; ABREU-SILVA, A.L. Prevalency and risk factors associated with brucellosis in cattle in the municipality of São Francisco do Brejão, Maranhão, Brazil. International Journal of Agriculture Innovations and Research, v.3, n.2, p.544-549, 2014.

ROCHA ALENCAR, R.D. Brucelose: epidemiologia e fatores de risco da Brucella abortus no rebanho bovino do sudoeste maranhense. Mestrado em (Ciência Animal) - Universidade Estadual do Maranhão, São Luís, 2016. Available from: http:// www.cienciaanimal.uema.br/images/diss/diss-2016/reylan.pdf. Accessed on: Oct 152016

SANTOS, H.P.; TEIXEIRA, W.C.; OLIVEIRA, M.M.M.; PEREIRA, H.M.; OLIVEIRA, R.A.; NEGREIROS, R.C.; SOARES FILHO, P.M.; SANTANA, S.S.; CASTRO, R.S. Brucelose bovina e humana diagnosticada em matadouro municipal de São Luís/MA, Brasil. Ciência Veterinária nos Trópicos, v.10, n. 2/3, p. 86-94, 2007.

SANTOS, R.P.; DENADAI, L.B.; SOUSA, D.R.; DONATELE, D.M.; NUNES, L.C.; MADELLA-OLIVEIRA, A. Lesões cervicais granulomatosas não estão associadas a brucelose bovina no sul do estado do Espírito Santo, Brasil. PUBVET, v.10, n.9, p.885$889,2016$.

SCHNEIDER, R.C.; SANTOS, M.D.; LUNARDI, M.; BENETTI, A.H.; CAMARGO, L.M.; FREITAS, S.H.; NEGREIRO, R.L.; COSTA, D.S. Prevalência da brucelose e fatores de risco associados a sua transmissão em trabalhadores de indústria frigorifica da região metropolitana de Cuiabá, Mato Grosso. Semina: Ciência Agraria, Londrina, v.34, n.5, p.2367-2374, set./out. 2013. Available from: http://www.uel.br/revistas/uel/index.php/semagrarias/ article/view/13558. Accessed on: Sep. 14 2015. http://dx.doi. org/10.5433/1679-0359.2013v34n5p2367

SOLA, C.M.; FREITAS, F.A.; SENA, E.L.S.; MESQUITA, A.J.M. Brucelose bovina: revisão. Enciclopédia Biosfera, Centro Científico Conhecer, Goiânia, v.10, n.18, p. 686, 2014.

TRIOLA, M.F. Introdução à Estatística. 7. ed. Rio de Janeiro: LTC, 1999.

VIANA, L.; BAPTISTA, F.; TELES, J.; RIBEIRO, A.P.C.; PIGATTO, C.P. Soropositividade e lesões sugestivas de Brucelose em bovinos abatidos no estado do Tocantins, Brasil. Arquivo do Instituto Biológico, São Paulo, v.77, n.3, p.517-520, jul./set. 2010. Available from: http://www.biologico.sp.gov.br/docs/ arq/v77_3/viana.pdf. Accessed on: 18 May 2015. 